\title{
Examination of the Argumentation Processes of Classroom Teachers Participating in On-the-job Training Activities
}

\author{
Menşure ALKIŞ KÜÇÜKAYDIN* \\ Amasya University Institute of Social Sciences, Amasya, TURKEY
}

\begin{tabular}{|c|c|}
\hline Amasya University Fac & y of Education Primary Education Department, Amasya, TURKEY \\
\hline Article history & In recent years, attention has been given to learning of the science \\
\hline $\begin{array}{l}\text { Received: } \\
28.03 .2016\end{array}$ & $\begin{array}{l}\text { language. This has brought together a transformation in science education } \\
\text { programs and the implementation of argumentation applications that is a }\end{array}$ \\
\hline $\begin{array}{l}\text { Received in revised form: } \\
24.05 .2016\end{array}$ & $\begin{array}{l}\text { part of this transformation. However adequate training has not been given } \\
\text { to teacher son revised } 2013 \text { science program in Turkey and on } \\
\text { argumentation practices. This situation has constituted the rationale for }\end{array}$ \\
\hline $\begin{array}{l}\text { Accepted: } \\
24.05 .2016\end{array}$ & $\begin{array}{l}\text { this case study. In line with the needs analysis a revised science } \\
\text { curriculum and on-the-job (OJT) training activity on argumentation has }\end{array}$ \\
\hline Key v & been prepared for classroom teachers. First a pilot application prepared \\
\hline $\begin{array}{l}\text { Argumentation practices, } \\
\text { argumentation activity, } \\
\text { argumentation skills, on-the-job } \\
\text { training, classroom teachers. }\end{array}$ & $\begin{array}{l}\text { and then the main application have been conducted. At the end of these } \\
\text { applications the argumentation skills, opinions on OJT activities and } \\
\text { activity preparation based on argumentation skills of teachers have been } \\
\text { examined. The findings of this study have revealed that classroom } \\
\text { teachers are not adequate in creating the opposite argument of the } \\
\text { argumentation components that they have been restrictive, and that they } \\
\text { have used the supportive evidence rationale in a limited way in an } \\
\text { argumentation activity they have practiced in their classroom. They have } \\
\text { been unable to reach the confuting stage. Nevertheless the classroom } \\
\text { teachers who have participated in OJT activities think that these activities } \\
\text { are useful in professional and personal point of view and that they should } \\
\text { be repeated at regular intervals. }\end{array}$ \\
\hline
\end{tabular}

\section{Introduction}

Educational researches started giving importance in scientific process skills and basic life skills, focus on the use of approach and methods that foresee the changes in today's condition. Elementary Science Curriculum that has been revised in 2013 and that in particular indicates "science literacy" as its fundamental vision can be showed as an example of one of these focuses (Ministry of Education, 2013). Integrating social scientific, cultural and social issues with science and technology the new developed program discusses a group of pedagogical requirements which also consists of argumentation.

Since the last decade scientific language has been seen as an important factor in learning, the role of learning science has been debated. It is important to understand the scientific concepts 
over the students' perceptions about science. Argumentation is effective in enhancing the epistemic and conceptual learning in science education. The development of conceptual understanding of students is necessary for a proper argumentation (Kaya, Erduran \& Çetin, 2010). Argumentation can be defined as social interaction and a thinking process through which individuals generate critical arguments (Nussbaum, 2011). According to O'Keefe (1982) the concept of argument is two-dimensional. While students to structure the arguments of others and to criticize them is important in the first dimension a supportive argument structure which is known as dialectical argumentation that contradicts through an anti-thesis occurs in the second dimension. Argumentation has a critical role in validity and generalize ability of scientific knowledge and assists the students in developing habits of important information in the brain (Walker et al. 2012). Thus, a solid argument structure generated for students is actually effective in cognitive development. Students not only develop their scientific skills they also change their perspectives during daily conversations through argumentation. Moreover, they also become able to create a high level written scientific arguments (Sampson, Grooms \& Walker, 2010).

It is possible to show an argument consists of a claim, an evidence and evaluation of the evidence as the main structure of development of argumentation framework. Claim is an assumption, a result, a description, or a response to the main or other research question. Evidences are derived from research findings and in this context knowledge and evidence are different concepts. The researchers either gather information or obtain evidences using the results of other researches. Nevertheless, a group comparison of the evidences presented should be conducted to be sure of the accuracy. Students often confuse information and the evidence (Chen, Lin, Hsu \& Lee, 2011) and give place only to information in their arguments. Yet some students try to transfer the information to evidence and therefore conducting an improper data analysis they misinterpret the analysis results. Some students tried to transfer the knowledge and evidence so by improper data analysis. These students confirm bias and only try to make their ideas to be accepted (Sampson, Enderle \& Grooms, 2013). According to Ryu\& Sandoval (2012) the students cannot fully separate especially claim and evidence and mention the difficulty to create a quality argument. The reason for this is the limited intervention to the students in this regard. From a socio-cultural perspective a change in classroom culture towards argumentation is necessary rather than brief interventions. For this purpose according to Walton (1989) argumentation skills should be developed and this development should be based on two factors. The first factor is to secure oneself from the arguments of the other party and the second is to strengthen her own position detecting the weaknesses of the arguments of the other party. The aim of argumentation is generating an undeniable guarantee supporting the claim and showing that this is a justified belief (Osborne \& Patterson, 2011). However, according to research results students present personal evidences and use cognitive and social strategies during argumentation process. On the other hand the strategies teachers use in the courses affect the scientific skills of students (Özdem, Ertepınar, Çakıroğlu \& Erduran, 2013). For argumentation adequacy, arguments should be understood, discussion, data and model information should be introduced, the adequacy of the targets should be focused and the targets should be ensured to be criticized (Böttcher \& Meisert, 2011).

\section{Literatüre Review}

In general it is possible to say that argumentation is a social activity. Toulmin model especially aims at improving the dialogical argumentation of students (Nielsen, 2013). This model intends to ensure students to understand the special problems and to evaluate the 
argumentation quality in classes (Konstantinidou \& Macagno, 2013). In Jimenez-Aleixandre \& Erduran, 2007, p.11) they defined the potential contributions provided by the argumentation as follows: be a field of social area, focus on a number of life skills such as critical thinking and persuasion, address to the scientific process skills such as introduction to scientific culture and scientific literacy. Based on the fact that argumentation is a social structure area argumentation should not only given a place in educational programs, but it also should be given attention for being a cognitive model as well as on its social and cultural structure. The model proposes the following suggestions to increase the argumentation skills Driver, Newton \& Osborne (2000) to inform with engagements that will improve the argumentation quality, to inform teachers and to help students to develop their arguments, to help teachers to become aware of the structure and nature of students' arguments, to teach teachers assessment skills to monitor the progress of the arguments. In the last decade many studies examining the impact of argumentation on student's acquisitions have been conducted (Kuhn \&Udell, 2003; Garcia-M1la, G1labert, Erduran \& Felton, 2013; Kıngır, Geban \&Günel, 2011; Akkuş, Günel\& Hand, 2007; Demirbağ\&Günel, 2014; Uluçınar-Sağır, 2008). While a major part of the studies refer on the importance of argumentation practices (Walton, 2006; Newton, Driver \& Osborne, 1999; Berland \&Reiser, 2008; Norton-Meier, Hand, Hockenberry\& Wise, 2008; Zohar \& Nemet, 2002; Sampson \& Clark, 2009), some studies have focused on the impact of argumentation teaching (Tümay \&Köseoğlu, 2011; Kaya, 2012; Şekerci, 2013; Ceylan, 2010; Hakyolu, 2010;Erdoğan, 2010; Ceylan, 2012; Peker, Apaydın \&Taş, 2012). Argumentation practices are important for the development of students' scientific literacy and the teachers have the key role in the organization of argumentation activities in science courses (Xie\& So, 2012). Indeed according to studies teachers do not use arguments while they explain theories, laws, models and unifying concepts from various disciplines (Sampson \& Blanchard, 2012). Yet, revealing the false arguments is an inevitable and a vital part of learning. The arguments offered by each of the learners can help deeply understanding of knowledge and building new knowledge (Mualler \&Yankelewitz, 2014). The influence of a teacher in learning and teaching science, his practical skills are affected by the decisions taken and action perspective (Sampson \&Enderle, 2013). Therefore, for a quality argumentation the teacher must be aware of the students' argumentation practices (Braund, Scholtz, Sadeck \&Koopman, 2013). At this point, we face teacher training and qualifications. In researches while the qualifications of the candidate teachers have been examined sometimes (Yıldırır \&Nakiboğlu, 2013). Argumentation skills have been examined in a limited number (Simon, Erduran \& Osborne, 2006; Simon \& Johnson, 2008; Günel, Kıngır \&Geban, 2012; Martin \& Hand, 2009). However, especially primary school teachers' level of argumentation practices and skills in argumentation processes have not been studied in detail yet. At this point, the need emerges to organize an OJT activity for elementary school teachers intending the introduction of argumentation and afterwards a monitoring study on teachers' practice skills.

\section{On-the-job Training Activities in Turkey}

The studies to improve the impact and adequacy of services conducted by experts in the field with the purpose to improve professional knowledge, skills and experience as well as to ensure motivation of individuals working in a particular institution to enhance to follow the innovations and to progress can be called on-the-job training (Özmen \& Kaya, 2013). Information collected before the service can sometimes be inadequate, or even if it is adequate there might be a need for replacement. The reasons of these changes can be listed as rapid advances in science and technology, personal development mobility, "career" planning or improving know-how and experience (Bilgin, Akay, Koyuncu \&Haşar, 2007). On-the-job 
training (OJT) activities in Turkey are carried out by On-the-job Training Department under On-the-job Training Regulation. OJT activities are mostly conducted centrally without a distinction of branch needs (Gökdere \&Küçük, 2003). The teachers have stated that they have felt discomfort because the activities are usually boring, obligatory, conducted in inappropriate time and by unqualified persons for many studies on OJT practices they have participated in (Arıbaş \&Göktaş, 2014; Gönen \&Kocakaya, 2006; Önen, Mertoğlu, Saka \&Gürdal, 2010; Karaca, 2010;Şener, 2009). The need has been revealed that OJT activities should take the changes in the program into account, and be designated in an area which is appropriate and necessary for the class teachers. Hence, teachers' training itself has to be a dynamic process, to avoid the repetition of the same issues and to enhance the collaboration among the sides (Ramatlapana, 2009). From this point on the aim of this study is the introduction of argumentation a method brought in and suggested by the revised course of Science Curriculum 2013 to the elementary school teachers. Afterwards a follow-up study should be conducted to monitor the argumentation skills of classroom teachers. Accordingly the research questions are;

1. What are the argumentation processes of class teachers at the end of the pilot on-thejob training application on argumentation?

2. What are the opinion of class teachers on argumentation practices after the main application?

3. How are the argumentation processes and activity preparation qualities of the class teachers after the main application?

\section{Method}

The research intends to assess the argumentation skills of elementary school 4th grade teachers, argumentation trainings they bring to the classroom, and generally the OJT activities they have received. The research has been designed according to the specific situation study. In the first phase of the research on the base of maximum diversity sampling needs analysis of the class teachers for argumentation has been conducted, an OJT activity has been designated in line with the feedbacks from the teachers. The needs analysis results have revealed that the class teachers have not participated in any OJT activity on revised program and that they have heard the word of "argumentation" for the first time. The legal permissions are obtained for the OJT activity designated accordingly and the pilot application has been performed in Tokat province, Turhal district. After the application a course of a participant has been monitors in the aspect of argumentation skills. During the last phase of the research the main application has been carried out during the teachers' seminar period in September 2015 and a general assessment of the applied activity has been completed.

\section{Application}

This study evaluating the data of an OJT activity on the argumentation consists of three phases. During the first phase of the study a pilot application has been conducted (AlkışKüçükaydın \&Uluçınar-Sağır, 2015). After the application, instead of sampling, a volunteer teacher has been chosen among the participants of OJT activity. The volunteer teacher's course throughout the chapters "Let's know the Substance" and "Light and Sound" has been observed for 7 hours. The observation has been carried out in 2014-2015 academic year spring semester. The class teacher who volunteered for the observation is a male participant who has 5 years of experience as teacher and who works at a village school. He thinks to have a constructivist teaching approach. The data obtained from observations have been coded and presented in findings. The main application part of the study has been conducted with volunteer teachers in line with the suggestions from the teachers as the result of pilot 
application in Tokat province at the beginning of 2015-2016 academic year. 34 classroom teachers have attended the program. A questionnaire has been distributed to get the thoughts about the shortcomings or advantages of the program after the OJT program. The questionnaire consists of 5 questions about the advantages of these activities, their ideas on the contribution of argumentation practices to professional and personal development. In the last phase of the research 3rd and 4th grade Science classes' gains are distributed among the participated teachers and they have been asked to prepare an argumentation event in their classes.

While developing the OJT program, attention has been paid at design, preparation, application, assessment, and monitoring stages. The program consists of topics of introduction to 2013 Science course curriculum, introduction to argumentation, implementation of argumentation practices and evaluation.

\section{Data Collection Tools}

An unstructured observation has been conducted with a teacher involved in the activity after pilot study. Data has been collected on video during the observation. The first author of this study has conducted a 7 hours long observation with video camera and has taken notes at the same time. The data obtained via video records have been written and together with the notes they have been analyzed. An observation form called "Coding the argumentation processes" designated by Simon et al.(2006) in order to measure the class teachers' argumentation skills after OJT activity. The observation form consists of the dimensions of speaking and listening, knowing the meaning of the argument, being a party, justifying the accuracy with proof, constructing arguments, evaluating arguments, creating the opposite argument/debating, and reflecting the argument process. After the training a questionnaire has been distributed in order to collect participants' opinion. The questionnaire consists of five questions on the content, quality, and effectiveness of OJT as well as on how much interest can be drawn to argumentation. Expert opinion has been requested before the questionnaire has been designated. Opinions of two teachers have been received to test the comprehensibility of the questionnaire. The final version of the questionnaire has been distributed to the participant teachers after OJT activity.

\section{Data Analysis}

During the pilot study data collected by video recording has been transferred into written documentation, in line with argumentation skills observation form descriptive analysis has been conducted. Data obtained from the questionnaire used after the main application are summarized in tables and direct references through descriptive analysis are used. The argumentation activities prepared by class teachers after the main application have been analyzed also in this context.

\section{Findings}

The data obtained from this research are presented according to the research questions of this study below.

Whatare the argumentation processes of class teachers at the end of a pilot on-the-job training application on argumentation?

In the first part presented below, findings related to argumentation process obtained from the 
voluntary participants are summarized on the analysis of the observation form in Table 1 seeking answers to the first research question.

Table 1. Argumentation process skills form obtained from the volunteer participants post pilot application

\begin{tabular}{|c|c|c|c|c|}
\hline $\begin{array}{l}\text { Argument } \\
\text { Process }\end{array}$ & Codes & Frequent & Sometime & Never \\
\hline Talking and & Encourages discussion & $*$ & & \\
\hline listening & Encourages listening & $*$ & & \\
\hline Knowing & Defines argument & $*$ & & \\
\hline $\begin{array}{l}\text { meaning of } \\
\text { argument }\end{array}$ & Exemplifies argument & $*$ & & \\
\hline \multirow[t]{3}{*}{ Positioning } & Encourages ideas & $*$ & & \\
\hline & Encourages positioning & & $*$ & \\
\hline & Values different positions & & $*$ & \\
\hline \multirow{6}{*}{$\begin{array}{l}\text { Justifying with } \\
\text { evidence }\end{array}$} & Checks evidence & $*$ & & \\
\hline & Provides evidence & & $*$ & \\
\hline & Prompts justification & $*$ & & \\
\hline & Emphasizes justification & $*$ & & \\
\hline & Encourages further justification & $*$ & & \\
\hline & Plays devil's advocate & $*$ & & \\
\hline $\begin{array}{l}\text { Constructing } \\
\text { arguments }\end{array}$ & $\begin{array}{l}\text { Uses writing frame or written work/ prepares } \\
\text { presentations/gives roles }\end{array}$ & $*$ & & \\
\hline Evaluating & Encourages evaluation & $*$ & & \\
\hline arguments & $\begin{array}{l}\text { Evaluates arguments process - using } \\
\text { evidence/content - nature of evidence }\end{array}$ & & $*$ & \\
\hline \multirow{2}{*}{$\begin{array}{c}\text { Counter-arguing/ } \\
\text { debating }\end{array}$} & Encourages anticipating counterargument & $*$ & & \multirow{4}{*}{ * } \\
\hline & Encourages debate (through role play) & & & \\
\hline Reflecting on & Encourages reflection & $*$ & & \\
\hline argument process & Asks about mind-change & & $*$ & \\
\hline
\end{tabular}

\section{Talking and listening}

The teacher presented the following statement in a conceptual change text he prepared related to the Chapter of "Light and Sound" to the students and asked them to discuss about it: "The sound moves faster than light, and moves in a linear form in all directions as the light". He tried to explain the students listen to each other and be open to debate as follows:

"Teacher: ..... for example someone formed the sentence wrong, Abdulhamid, why did you do this way? Come here, tell your friends, yes, children, we're listening now."

Student: Teacher, I thought light behaves like sound.

Teacher: Okay, children, is there any of you who thinks like your friend? What did he say?"

The teacher asked his students about the vehicle to move the patient after an accident during another argumentation introduction session. He asked for their rationale and motivated them to present their rationale.

Teacher: Uluhan, what did you choose?

Student: Aircraft.

Teacher: Why?

Student: Teacher, I chose it because it moves very fast.

Teacher: Yes, explain. 
Student: Teacher, it can go so fast since there is no traffic in the sky. The likelihood of an accident in the sky is very little, um teacher, likelihood of an accident on asphalt road is higher therefore I chose the aircraft.

Teacher: Do you think your option would always be valid?

Student: Most of the time my teacher.

\section{Knowing meaning of argument}

In this dimension the statements the teacher used while introducing argumentation items to the student are as follows:

"Teacher: Now children, together we will try a new method. The name of this method is argumentation. We can also call it scientific debate. Now, what is the difference of this method from the methods we have been using in our science classes before? Now, we put a claim forward in argumentation. But first, we have data in hand. But we have a limiting item in this claim, e.g; probably, definitely, possibly ... Then we will try to prove our claim with some rationale. Then we will support it. The other party will try to disprove it. While explaining this seems abstract. Now, I will explain this through examples. Okey? Now, we'll make a prediction observation statement together. You will understand better, I will also explain to you, okay?"

The next course during the activity called "baby sitter" he presented to teach the argumentation the teacher introduced the components of argumentation to the students as follows:

Teacher ": I think you start to defend yourself, suggest strong rationale to make the other party to accept your claim.

Student: How shall we make the claim?

Teacher: What was the claim? Remember ... What did you write on the space on the research question?

Student: We choose to baby sitter called Anil, teacher.

Teacher: You choose Anll, so you made a claim. Now you have to prove this claim. Support it, reason it."

During the oral argumentation process the teacher who forms the groups and who wants the students to ask the opinion of the other group makes the following statement:

"Teacher: Children, at this stage you are not supposed to discuss with the group you visit, you are supposed only to ask. You as why they have made these claims? Why not another?".

\section{Positioning}

In the stage of evidence evaluation of argumentation teacher has been observed to detect whether he puts importance on the facts of "what they think, how they support and the accuracy of the grounds". During argumentation session on conceptual change text on light and sound the teacher has tried to make the students to talk with expressions such as "Why, how, explain!" in order to motivate them for different ideas however he has not been adequate to motivate them in being a party after different ideas have been put forth and to suggest the 
different positions in the same frequency. The following example shows that the teacher tries to get the opinion of the student who gives the right answer while he is saying "no" with his head to the student who gives the wrong answer.

"Teacher: Yes, the text says that sound moves faster in gas, right or wrong?

Student 1: Wrong, teacher.

Student 2: But, isn't that right, teacher?

Teacher: (recognizes the $1^{\text {st }}$ students) Okay, explain.

Student: Because, teacher, they are not so close together... "

\section{Justifying with evidence}

During the argumentation practices teacher has been expected to teach the student "why does he think so, that he has to prove it, that he has to question the strength of his proves". The following speech has been observed during "baby sitter" session:

Teacher: Why others do not be selected and your group to be selected?

Student: Because she gets along well with children. If the room is untidy when Mrs. Arzu comes home she makes the children to tidy up the room and can be an good example.

Teacher: Yes ... your evidences and supports?

Student: Teacher, since we like sports we can teach sports to the children. This sport lesson can keep the children healthy. Also since we like to watch TV we can make the children to watch educational TV programs. Or if we like to watch other programs we watch after we put the children to sleep. We should not buy ready food since they contain additives, we can cook for ourselves.

Teacher: Well, now we hear about Suna. Why would they choose Suna. We listen to your claims."

In another lesson during the session on the characteristics of solid materials with tiny particulars the teacher has said in order to discuss the ideas of the students:

"Teacher: Why does rice stays like this in the glass, isn't rice solid?

Student: Teacher, it is solid but in tiny particles.

Teacher: Is it solid because it is in tiny particles?

Student: Some solids are fluid but still solid.

Teacher: How do you know that it is solid?

Student: Teacher, because it is hard.

Student: Teacher, it occupies space.

Teacher: Okay, but do only solids take up space?

Student: No."

\section{Constructing arguments}

The teacher has preferred also written argumentation in introducing argumentation and in all other activities. In particular, during the "baby-sitter" session used to introduce the argumentation he has presented blank template of the research question, claim, rationale and support written on the back side of the paper. He has distributed a text on estimation, observation, description during the session related to the chapter of Substance and a text of conceptual change during the session related to the chapter of Light. He has asked the students to present their rationale verbally and written. 


\section{Evaluating arguments}

On the component related to the evaluation of arguments; during the observations the teacher has evaluated the argumentation components only during "baby sitter" session used for the introduction of argumentation however he has not evaluated argumentation components during estimation- observation- description, conceptual change text and other class events.

"Teacher: Yes, why didn't you support another claim but this one?

Student: Teachers, Firat likes to read books to the children. That's why.

Teacher: Okay, so these are your claims. Now let me tell your rationales.

Student: Well, he can cook, then ...

Teacher: Also use limiting expressions. What are they? Most likely, probably, most of the time...

Student: Most likely he can prepare meals. Definitely he can feed the children by cooking delicious food with recipes from the cookbook or social media.

Teacher: Well, how can you disprove of the claims of your friends in the group that chose Anıl?

Student: Teacher, for example Anul is such very polite. He would treat the children gently.

Teacher: Well, these are your claims, what are your evidences?"

\section{Counter-arguing/debating}

During the session related to the substance in activities based on argumentation the teacher waits for the students to think and respond an opposing argument to the answer of the student.

"Teacher: How do we know that rice is solid?

Student1: Unbreakable.

Teacher: Your friend says that it is unbreakable.

Student 2: But, teacher, we can break pencil."

In another lesson, the teacher says the following for the opposing arguments:

"Teacher: Children, also think what the opposing group may suggest against you!

Student: Teacher, we already take their shortcomings into account. We will write evidences accordingly.

Teacher: Yes. For example, now leaders of the group will remain in place, the members will go and ask. Why did you choose this baby sitter, what qualifications does he have? What are your claims, evidences, and reasons? Then, come back to your groups and think and estimate on what you have learned. What can we say to disprove them."

But the teacher's role-playing and encouraging behavior while discussing opposing arguments could be observed.

\section{Reflecting on argument process}

According to the observation the teacher motivates reflection in order to encourage the students during his lessons based on argumentation but he does not uncover whether the students' opinion change or not or the rationale behind it. 
"Teacher: So, can you give an example? Can anyone say, teacher, light moves faster, this is proof for that. Does anyone have a good explanation?

Student: Thunder, teacher, because first comes the light. After the light comes and goes the sound comes.

Teacher: Can it be like this? There has been light somewhere, we might have seen that light. Then we might have heard the sound. Can it be such a thing?

Student: No, teacher. It happens at the same time, at the same moment.

Teacher: Yes. Isn't that right, children? Also thunder, both happens at the same time. As Taha says."

In the second part of the study data is presented obtained from the teachers at the end of the main application. These data is presented in order to seek answer to the second research question.

What are the thoughts of the class teachers on the argumentation practices after the main application?

After the OJT activity a form with five questions has been distributed to the participating teachers to get their opinions and suggestions on the activities. The ratios and frequencies obtained from the participants are presented in Table 2, unanswered questions are not included.

Table 2. The proportions of percent and frequency of activity evaluation results

\begin{tabular}{lcc}
\hline \multicolumn{1}{c}{ Questions / $(\mathrm{n}=34)$} & $f^{\prime}$ & $\%$ \\
\hline $\begin{array}{l}\text { Do you think you had enough time to achieve activity aims? } \\
\text { Were there enough examples about argumentation and do you think the }\end{array}$ & 20 & 59 \\
applications were sufficient? & 28 & 82 \\
$\begin{array}{l}\text { Can you use the information you got about argumentation in your } \\
\text { classroom? }\end{array}$ & 32 & 94 \\
$\begin{array}{l}\text { Did you realize any deficiencies or problems in your service training } \\
\text { activity? }\end{array}$ & 2 & 6 \\
$\begin{array}{l}\text { Do you think this service training activity will contribute to your personal } \\
\text { and professional development? }\end{array}$ & 34 & 100 \\
\hline The number of positive responses to the questions on the question form
\end{tabular}

Percentage and frequency values of the responses: 59\% of respondents state that the activity is adequate in terms of achieving the objectives while $41 \%$ state that the activity should be conducted at regular intervals rather than a day. The frequency of the positive responses to the question on the adequacy of the examples related to argumentation is $82 \%$. The participants who think that the examples are not adequate response as follows: "Examples corresponding for more gains should have been presented", "Argumentation examples could be presented also for other lessons." According to the obtained data the percentage of those who consider to use argumentation practices in class is $90 \%$. These respondents state that they argumentation is not a demanding method even if they do not use. The percentage of the participants who think that they have had discomforts during the activity is $6 \%$. The discomfort is mainly caused by other participants who have not fully participated in group activities. They state that their enthusiasm have been weakened for this reason. The entire participants think that the OJT activity they have participated in is definitely a developmental opportunity for them and express: "I think every course has an impact on professional development, more or less, but definitely will have." 
How are the argumentation processes and activity preparation competencies of classroom teachers after the main application?

With the purpose of finding the answer for the third question of this study the teachers participated in the activity are asked to form groups and to prepare an argumentation activity that they can use in their classes. The example of activity prepared by two groups of participant teachers is presented below.

Example 1. Research Question: Can Force alter the shape of all objects?

Claim: adequately applied force changes the shape of the object.

Evidence: Force applied to the wall by hand does not lead to change in shape.

Force applied to the wall by sledgehammer causes change in shape.

In the above presented example of argumentation activities classroom teachers have written a research question, but they haven't used limiter, supporter, evidence rationale, and disprove which are the main scientific components of an argumentation. In addition the participant teachers have presented in sufficient evidence against the claim that they have suggested.

Example 2. Research Question: which one of the five senses would you sacrifice? (If you need to)

Your Claim: I would sacrifice my ear.

My evidences: our life quality decreases more if we lose the others.

It is possible to compensate, non-verbal communication can be established.

Education can continue.

Lip reading can be learned.

Medicine is more successful in this area.

Mass media can be used.

My evidence rationale: Experiences of people with disabilities around us.

Activity in argumentation presented in Example 2 demonstrates the lack of limiting and disproving expressions, similar to Example 1.Still, in this example, participating teachers have used the evidence ground, they provide more evidence than the previous example. None of the participants teachers after the main application have included delimiter and rebuttal expressions in the argumentation activity they have prepared.

\section{Discussion and Conclusion}

In this study conducted with the class teachers conducted in OJT activity, primarily a pilot application has been conducted and as the result of this application the lessons of a volunteering teacher has been observed. According to the result of observation the teacher is found adequate in speaking and listening skills. Indeed according to Simon et al. (2006) for a proper argumentation, the students should listen and respond to each other in a collaborating structure. The teachers should use proper argumentation discourse strategies so that the argumentation skills of children in younger age group improve (Kuhn \&Udell, 2003). In the lessons argumentation is applied the most significant changes a student experience occur during the evidence evaluation phase (Sampson et al.2013). During observations the teacher encourages the students to talk through sample text but cannot completely fulfill the ability to be a party. Yet, sometimes he may be have the ability to structure the arguments. According to Sampson et al. (2010)the teacher may encourage the students to debate as well as ask them to submit written arguments in the argumentation activities. It is possible to say that the teacher has successfully presented written and verbal argumentation samples during observation. The teacher cannot always capture the same level of success in evaluation of the 
arguments of the students. However according to Simon et al. (2006) during argumentation applications teachers can ask questions to the students for evaluating their arguments. This way he would emphasize the importance and the nature of evidences. The observed teacher has been successful in introducing the meaning of argumentation to the students. In argumentation applications the students are expected to think and evaluate the arguments of the other party while they are debating their arguments. However, the teacher cannot fulfill the role-playing skills at all has been observed during observation could not fulfill at all. In the lessons during which argumentation applications are carried out, it is important that the teacher supports the students to create more proper arguments (Osborne et al.2006). The class teacher has remained inadequate particularly in encouraging debates. He has had difficulties in evaluating the claims and arguments. Also according to the study Zohar (2007) has conducted the teachers generally fail in forming arguments and in creating mutual arguments in the class. According to Zembal-Saul et al. (2002) the reason for this is that the candidate teachers and the teachers have very little information in introduction to a scientific argumentation. The claims the teachers put forward for an argument are insufficient and the evidences do not include a complicated structure. Moreover, the claims generally have similar structures. The teachers' failure in presenting adequate claims and in encouraging to debate Rice (2009), Clark \& Sampson (2008) is connected to weak branch knowledge. So in a scientific argumentation process the lack of branch knowledge and conceptual knowledge can be effective.

All class teachers who have received OJT on argumentation think that the activity has been useful for their professional and personal development. As Kaya, Küçük and Çepni (2004) indicates that along with courses in which the needs and emotional development of the teachers are noted teachers' attitude towards the OJT courses has changed positively correlates with the research results. The participants think that this activity should be repeated at regular intervals, they also want more activities on science courses. As Şenel (2008) indicates the teachers believe that the recurrence of these activities will increase persistence in the long-run. According to Huffman (2006) the persistence of reforms of science education can be achieved only through the approaches that enhance the teachers to adopt new ideas by recurrences in the long-run.

In the research the class teachers have been asked to prepare argumentation activities to be used in their own classes. But the teachers have used the limiter, supporter and evidence ground limited, they haven't included rebuttal components at all. Nonetheless rebuttals are important in a scientific argumentation because rebuttals contain a complicated structure and play role in developing multi perspective (Osborne et al.2004). Literature studies show that the majority of the students cannot reach the confuting stage (Berland\&Reiser, 2009). In this process teachers should be models since the students are not used to critical scientific argumentation. According to the researches as the number of open ended questions increase during the lessons the number of students' claims and confuting increase (McNeill \& Pimentel, 2010). Also claim, confuting and rationale have a critical role in basic evaluation and development of a scientific argumentation (Erduran et al. 2004). Therefore if the teachers do not use the main components of argumentation avoids the formation of a scientific argumentation structure. Parallel with this study the studies conducted by McNeill \& Pimentel (2010) can be shown as example. In that study the argumentation structure of three teachers on climate change have been examined and only one of them has been observed to reach at the claim and confuting level via teacher-student interaction. Hence the result reveals that the argumentation structures of teachers affect the argumentation structure of the students. 
Based on the findings obtained from the research results science knowledge branch competencies of the teachers can be examined to find out why the class teachers cannot use all the necessary components of a scientific argumentation. It can be found out whether this is caused by the lack of concepts based on branch knowledge on science courses or by a pedagogical shortcoming. Nonetheless based on the research and the relevant literature data, conducting needs analysis, organizing OJT activities for class teachers at certain intervals, and preparing sample argumentation activities on the group and individual achievements in these activities are recommended.

\section{Acknowledgements}

This research was supported by Amasya University SEB BAP 14-032 with project, headed by Associate Professor Şafak Uluçınar Sağır.

\section{References}

Akkuş, R., Günel, M., \& Hand, B.(2007). Comparing on inquiry-based approach known as the science writing heuristic to traditional science teaching practices: Are there differences? International Journal of Science Education, 29(14), 17451765.http://dx.doi.org/10.1080/09500690601075629

Alkış-Küçükaydın, M., \&Uluçınar-Sağır, Ş.(2015). In-service training argumentation application for elementary school teachers: Pilot study. ERPA International Congress on Education 2015 in Athena, Greece.

Arıbaş, S.,\&Göktaş Ö. (2014). Secondary school math teachers' views on necessities of inservice trainings for alternative measurement and evaluation.Journal of Adryaman University Social Science Institute ,7(16), 17-42.

Berland, L.K., \&Reiser, B.(2009). Making sense of argumentation and explanation. Science Education, 93(1), 26-55.http://dx.doi.org/10.10027sce.20286

Bilgin, K.U, Akay, A.,Koyuncu, H.E., \& Haşar, E.Ç.(2007). In-service training in local government. Türkiye Ekonomi Politikaları Araştırma Vakfi Yayınları (Economic Policy Research Foundation of Turkey Publications), Ankara, Turkey.

Böttcher, F.,\&Meisert, A.(2011). Argumentation in science education: A model-based framework. Science and Education, 20,103-140 http://dx.doi.org/10.1007/s11191-0109304-5

Braund, M., Scholtz, Z., Sadeck, M., \&Koopman, R.(2013). First steps in teaching argumentation: A South African study. International Journal of Educational Development, 33,175-184.http://dx.doi.org/10.1080/09500690601075629 10.1016/j.ijedudev.2012.03.007

Ceylan, Ç. (2010). Implementing the science writing heuristic (SWH) approach in science laboratory activities. Unpublished Master Thesis, Gazi University, Institute of Educational Science, Ankara, Turkey.

Ceylan, K.E. (2012). Teaching $5^{\text {th }}$ grades elementary students with scientific argument based method in the area of world and universe learning. Unpublished Master Thesis, Gazi University, Institute of Educational Science, Ankara, Turkey.

Chen, J.J, Lin, H.S, Hsu, Y.S., \& Lee, H.(2011). Data and claim: The refinement of science fair work through argumentation. International Journal of Science Education Part B: Communication and Public Engagement, 1(2), 147-164.

Clark, D.B., \& Sampson, W.(2008). Assessing dialogic argumentation in online environments to relate structure, grounds, and conceptual quality. Journal of Research in Science Teaching, 45, 293-321.http://dx.doi.org/10.1002/tea.20216 
Demirbağ, M., \&Günel, M.(2014). Integrating argument-based science inquiry with modal representations: Impact on science achievement, argumentation, and writing skills. Educational Sciences: Theory \& Practice, 14(1), 386391.http://dx.doi.org/10.12738/estp.2014.1.1632

Driver, R, Newton, P., \& Osborne, J.(2000). Establishing the norms of scientific argumentation in classroom. Science Education, 84(3), 287312.http://dx.doi.org/10.1002/(SICI)1098-237X(200005)84:3<287::AIDSCE1>3.0.CO;2-A

Erdoğan, S.(2010). Investigate the effects of teaching earth, sun and moon topics through argumentation on success, attitude and argumentation skills of $5^{\text {th }}$ grade students. Unpublished Master Thesis, Usak University, Institute of Social Science, Usak, Turkey.

Garcia, M.M., Gilabert, S. Erduran, S., \& Felton M.(2013). The effect of argumentative task goal on the quality of argumentative discourse.Science Education, 94(4), 497523.http://dx.doi.org/10.1002/sce. 21057

Gökdere, M., \&Küçük, M. (2003). Science education of gifted students at intellectual area: A case for science art centers. Educational Sciences: Theory \& Practice, 3(1), 118-124.

Gönen, S., \&Kocakaya, S. (2006). An evaluation of high school physics teachers' opinions about in service-education.Pamukkale University Journal of Education 19(1),37-44.

Günel, M., Kıngır, S., \&Geban, Ö.(2012). Analysis of argumentation and questioning patterns in argument-based inquiry classrooms.Education andScience, 37(164), 316-329.

Hakyolu, H.(2010). A performance of students at different science learning levels in the argumentation environment for science lessons. Unpublished Master Thesis, Marmara University, Institute of Education Science, Istanbul, Turkey.

Huffman,D.(2006). Reforming pedagogy: Inservice teacher education and istructional reform. Journal of Science Teacher Education,17, 121-136. http://dx.doi.org/10.1007/s10972006-9014-7

Jimenez-Aleixandre, M.P., \&Erduran, S.(2007). Argumentation in science education: An overview. Chapter In S.Erduran\&M.P.Jimenez-Aleixandre (Eds.), Argumentation in science education: Perspectives from classroom-based research (pp.3-29). Dordrecht, The Netherlands: Springer.

Karaca, A.(2010). Primary schools teachers opinions about in service training programs (Mudurnu case). Unpublished Master Thesis, AbantİzzetBaysalUniversity, Institute of Social Science, Bolu, Turkey.

Kaya, A., Küçük, M., \&Çepni, S.(2004). Prepared an evaluation of training programs for physics laboratory services, Pamukkale University Journal of Education, 16, 89-103.

Kaya, E.(2012). Impact of activities based on argumentation to subject teachers to understand the chemical equilibrium. X.Ulusal Fen ve Matematik Eğitimi Kongresi 2012, Niğde, Turkey (X.National Science and Mathematics Education Congress 2012, Niğde, Turkey)

Kaya, E., Erduran, S., \&Çetin, P.S.(2010). High school students' perceptions of argumentation.Procedia Social and Behavioral Sciences, 2, 39713975.http://dx.doi.org/10.1016/7j.sbspro.2010.03.625 09500690601075629

Kıngır, S., Geban, Ö., \&Günel, M.(2011). Students' ideas about the implementation of the argumentation based science inquiry approach in their chemistry course. Selcuk University Ahmet Kelesoglu Journal of Education, 32, 15-28.

Konstantinious, A., \&Macagno, F.(2013). Understanding students' reasoning: Argumentation schemes as an integration method in science education. Science and Education, 22, 1069-1087.http://dx.doi.org/10.10077s11191-012-9564-3 
Kuhn, D., \&Udell, W.(2003). The development of argumentation skills.Child Development, 74(5), 1245-1260.

Martin, A.M. ,\& Hand, B.(2009). Factors affecting the implementation of argument in elementary science classroom: A longitudinal case study. Research in Science Education, 39, 17-38.http://dx.doi.org/10.1007/s11165-007-9072-7

McNeill, K., \& Pimentel, D.S.(2010). Scientific discourse in three urban classrooms: The role of the teacher in engaging high school students in argumentation. Science Education, 94(2), 203-229.http://dx.doi.org/10.1002/sce.20364

Ministry of Education (2013). Primary education institutions of applied sciences curriculum. Board of Education, Ankara, Turkey.

Mueller, M., \&Yankelewitz, D.(2014). Fallacious argumentation in student reasoning: Are there benefits?.European Journal of Science and Mathematics Education, 2(1), 27-38.

Newton, P., Driver, R., \& Osborne, J.F.(1999). The place of argumentation in the pedagogy of school science. International Journal of Science Education, 21(5), 553576.http://dx.doi.org/10.1080/095006999290570

Nielsen, J.A.(2013). Dialectical features of students' argumentation: A critical review of argumentation studies in science education. Research in Science Education, 43, 371393.http://dx.doi.org/10.1007/s11165-011-9266-X

Norton-Meier, L., Hand, B.,Hockenberry, L., \&Wise, K.(2008). Questions, claims, and evidence: The important place of argument in childrens' science writing. Portsmoth, NH: Heinemann.

Nussbaum, E.M.(2011). Argumentation, dialogue theory, and probability modeling: Alternative frameworks for argumentation research in education. Educational Psychologist, 46(2), 84-106 http://dx.doi.org/10.1080/00461520.2011.558816

O'Keefe, D. J. (1982). The concept of argument and arguing. Chapter In J. R. Cox and C. A. Willard (Eds.), Advances in argumentation theory and research (pp. 3-23).

Carbondale, IL: Southern Illinois University Press.

Önen, F., Mertoğlu, H.,Saka, M., \&Gürdal, A.(2010). The effects of in service training on teachers' knowledge about project-based learning and competencies for conducting projects: Öpyepcase .AhiEvranUniversity Journal of Education,11(1), 137-158.

Osborne, J., Erduran, S., \& Simon, S.(2004). Enhancing the quality of argumentation in school science. Journal of Research in Science Teaching, 41(10), 9941020.http://dx.doi.org/10.1002/tea.20035

Osborne, J.F., \& Patterson, A.(2011). Scientific argument and explanation: A necessary distinction? Science Education, 95(4), 627-638.http://dx.doi.org/10.1002/sce.20438

Özdem, Y., Ertepınar, H., Çakıroğlu, J., \&Erduran, S.(2013). The nature of pre service science teachers' argumentation in inquiry-oriented laboratory context.International Journal of Science Education, 35(15), 25592568.http://dx.doi.org/10.1080/09500693.2011.611835

Özmen, F., \& Kaya, F.(2013). The effectiveness of English in-service training courses to which ministry supervisors attended.Furat University Journal of Social Science, 23(2), 115-124.

Peker, E.A., Apaydın, Z., \&Taş, E.(2012). Understanding of heat insulation with argumentation: Case study with primary 6th grade students. Dicle University Journal of Social Science Institute, 4(8), 79-100.

Ramatlapana, K.A.(2009.) Provision of in-service training of mathematics and science teachers in Botswana: Teachers' perspective.Journal Mathematic Teacher Education, 12:153-159. 
Roychowdhury, A., \& Rice, D.(2009). Discourse of making sense of data: Implications for elementary teacher's science education. Journal of Science Teacher Education, 21, 181-203.http://dx.doi.org/10.1007/s10972-009-9165-410

Ryu, S., \& Sandoval, A.W.(2012). Improvements elementary children's epistemic understanding from sustained argumentation. Science Education, 96(3), 488526.http://dx.doi.org/10.1002/sce.21006

Sampson, N., \& Clark, D.B.(2009). The impact of collaboration on the outcomes of scientific argumentation.Science Education, 93, 448-484.http://dx.doi.org/10.1002/sce.20306

Sampson, V., \&Enderle, P.(2013). Development and initial validation of the beliefs about reformed science teaching and learning (BARSTL) questionnaire. School Science and Mathematics, 113(1), 3-15.http://dx.doi.org/10.1111/j.1949-8594.2013.00175.x

Sampson, V., \&R.Blanchard, M.(2012). Science teachers and scientific argumentation: Trends in views and practice. Journal of Research in Science Teaching, 49(9), 11221148.http://dx.doi.org/10.1002/tea.21037

Sampson, V. Enderle, P., \& Grooms, J.(2013). Argumentation in science education.The Science Teacher, 30-33.

Sampson, V., Grooms, J., \& Walker, J.P.(2010). Argument-driven inquiry as a way to help students learn how to participate in scientific argumentation and craft written arguments: An exploratory-study. Science Education, 95(2),217257.http://dx.doi.org/10.1002/sce.20421

Şekerci, A.R.(2013). The effect of argumentation based instruction on students argumentation skills and conceptual understanding in Chemistry laboratory. Unpublished $\mathrm{PhD}$ Thesis, Atatürk University Institute of Educational Sciences, Erzurum, Turkey.

Şenel, T.(2008). Investigating the effectiveness of in-service course programmers for science and technology teachers about alternative measurement and assessment techniques. Unpublished Master Thesis, Karadeniz Technical University Science Institute, Trabzon, Turkey.

Şener, M.M.(2009). Of the class teacher training service levels influence motivation. Unpublished Master Thesis, Marmara University Institute of Educational Sciences, Istanbul, Turkey.

Simon, S., \&Johnson, S.(2008). Professional learning portfolios for argumentation in school science.International Journal of Science Education, 30(5), 669688.http://dx.doi.org/10.1080/09500690701854873

Simon, S., Erduran, S., \& Osborne, J. (2006). Learning to teach argumentation: Research and development in the science classroom. International Journal of Science Education, 235-260.http://dx.doi.org/10.1080/09500690500336957

Tümay, H., \&Köseoğlu, F.(2011). Developing pre-service chemistry teacher's understanding of teaching through argumentation.Journal of Turkish Science Education, 8(3), 105119.

Uluçınar-Sağır, Ş.(2008) Investigating of effectiveness of argumentation theory based teaching in science courses. Unpublished PhD Thesis, Gazi University Institute of Educational Sciences, Ankara, Turkey.

Walker, B.J.P., Sampson. V., Grooms, J. Anderson, B., \& Zimmerman, C.O.(2012). Argument-driven inquiry in undergraduate chemistry labs: The impact on students' conceptual understanding, argument skills, and attitudes toward science. Journal of Collage Science Teaching, 41(4), 74-81.

Walton, D.N.(1989). Dialogue theory for critical thinking. Argumentation, 3, 169-184.

Walton, D.N.(2006). Fundamentals of critical argumentation. New York: Cambridge University Press. 
Xie, Q., \& So, W.W.M.(2012). Understanding and practice of argumentation: A pilot study with Mainland Chinese pre service teachers in secondary science classrooms. Asia Pacific Forum on Science Learning and Teaching, 13(2), 1-20.

Yıldırır, H.E., \&Nakiboğlu, C.(2014). Examination of chemistry teachers and preserviceteachers'argumentation processes used in their courses.AbantizzetBaysal University Journal of Education, 14(2), 124-154.

Zembal-Saul, C. Minford, D. Crowford, B., Friedrichsen, P., \& Land, S.(2002). Scaffolding pre-service science teachers evidence-based arguments during and investigating of natural selection. Research in Science Education, 32, 437-463.

Zohar, A.(2007). Science teacher education and professional development in argumentation. Chapter In S.Erduran and M.P.Jimenez-Aleixandre (Eds.), Argumentation in science education: Perspectives from classroom-based research (pp.245-269). Dordrecht, The Netherlands: Springer.

Zohar, A., \&Nemet, F.(2002). Fostering students' knowledge and argumentation skills through dilemmas in human genetics. Journal of Research in Science Teaching, 39(1), 35-62.http://dx.doi.org/10.1002/tea.10008 